\title{
THE APPROVAL OF FREEHOLD TITLE IN INHERITANCE LAWSUIT AT GORONTALO RELIGIOUS COURT
}

\author{
Titin Samsudin \\ Lecturer at the State Islamic Institute Sultan Amai Gorontalo \\ Email: titin.samsudin@iaingorontalo.ac.id
}

\section{Nur Hairat Adam}

Students at the State Islamic Institute Sultan Amai Gorontalo

Email:hairat.nur@gmail.com

\begin{abstract}
Freehold Title acts as strong evidence of that certificate holder, as long as there is no other more reliable evidence. In Case Number. 0337/Pdt.G/2016/PA.Gtlo. authentic freehold title is declared not legally binding while in Case Number 38/Pdt.G/2012/PN.Gtlo., quite the opposite. This research is library research, with an empirical juridical approach. This study focuses on the verdict of the Gorontalo Religious Court in Case Number 0337/Pdt.G/2016/PA.Gtlo. The findings of this study are that the Gorontalo District Judicial Judge's verdict does not make the Gorontalo District Court decision as the basis. The panel of judges in the Verdict Number 0337/Pdt.G/2016/PA.Gtlo. emphasized more on the normative aspects in basing its verdict. The judge did not make a contextual approach in examining the condition of the defendant as an adopted child. The focus of the panel of judges is only on the procedure of making an authentic deed (grant deed), which is considered to be legally flawed and not legally binding. The courtesy of the judge in basing his consideration of the period of the plaintiff's claim filing, the excellent relationship of the defendant (adopted child) with the heir. The research findings imply that the distribution of inheritance should be carried out properly. The process of claiming inheritance in the Religious Courts of the panel of judges must continue to consider the duration of this new inheritance so that the trial process is not complicated to solve.
\end{abstract}

Sertifikat Hak Milik berlaku sebagai alat pembuktian yang kuat atas pemegang sertifikat tersebut, selama tidak ada alat bukti lain yang lebih kuat. Pada Perkara Nomor. 0337/Pdt.G/2016/PA.Gtlo. akta otentik SHM dinyatakan tidak berkekuatan hukum mengikat sementara pada perkara Nomor 38/Pdt.G/2012/PN.Gtlo., justru sebaliknya. Penelitian ini adalah studi pustaka (library research), dengan pendekatan yuridis empiris. Kajian ini difokuskan pada teks putusan Pengadilan Agama Gorontalo pada perkara No. 0337/Pdt.G/2016/PA.Gtlo. Temuan penelitian ini bahwa putusan hakim Peradilana agama Gorontalo tidak menjadikan putusan Peradilan Negeri 
Gorontalo sebagai dasar. Majelis hakim dalam putusan No. 0337/Pdt.G/2016/PA.Gtlo., lebih menonjolkan aspek normatif dalam mendasarkan putusannya. Hakim tidak menjadikan pendekatan kontekstual dalam menelaah kondisi tergugat sebagai anak angkat. Titik fokus majelis hakim, hanya tertuju pada prosedur pembuatan akta otentik (akta hibah) yang dianggap cacat hukum dan tidak berkekuatan hukum. Kealfaan hakim dalam mendasarkan pertimbnagannya terhadap rentang waktu pengajuan gugatan penggugat, hubungan baik tergugat (anak angkat) dengan pewaris. Implikasi temuan penelitian bahwa pembagian warisan memang sudah semestinya segerah untuk dilakukan, kemudian proses gugatan waris di Pengadilan Agama majelis hakim harus tetap mempertimbangan lamanya warisan ini baru digugat agar dalam proses persidangan tidak rumit untuk dipecahkan.

Keywords: Approval, Freehold Title, Inheritance.

\section{INTRODUCTION}

Inheritance is one of the crucial issues in human life. Through inheritance, the rights, obligations, and property will be transferred towards people, from one generation to another. Since the property is used by some people as a measure of luck in life, a chance for a dispute in possession of the inheritance will open up. ${ }^{1}$ Distribution of inheritance in Islam uses the legal basis contained in the Qur'an, among others in the Holy Quran Surah An-Nisa/4: 7. Islam regulates the portion between men and women in terms of inheritance, which is $2: 1{ }^{2}$ However, at present, this is not used by many heirs. Most use a system of sharing by deliberation and kinship. Distribution in this way was also ineffective, sometimes even causing problems in the future. So many inheritance distribution processes that occur at this time that end in court and not resolved even though there has been a legally binding decision.

The Islamic inheritance system in Indonesia until now, there has not been a legal entity regarding inheritance law that is applied to all Indonesian citizens. Therefore, inheritance laws that apply to all Indonesian citizens are still different. ${ }^{3}$ Given the pluralism of inheritance law, so the inheritance legal system in Indonesia consists of three legal systems, namely inheritance law according to Islam, Islamic Inheritance Law According to the Civil Code and Inheritance Law According to

${ }^{1}$ M. Syarkoni, Konflik Harta Warisan (1 ${ }^{\text {st }}$ Ed., Yogyakarta: Pustaka Pelajar, 2007), p. 1.

${ }^{2}$ Al-Mehri, A. B. (Ed.). The Qur'än: With Sürah Introductions and Appendices: Saheeh International Translation (Maktabah Booksellers and Publishers, 2010).

${ }^{3}$ Fatchur Rahman, Ilmu Waris (Cet. II; Bandung: PT Al Ma'arif, 1981). p. 16. 
Customary Law, ${ }^{4}$ and Compilation of Islamic Law concerning inheritance law in force in Indonesia.

The Compilation of Islamic Law (KHI) in Indonesia has explained of how the division of inheritance in Islam. Book II consisting of 6 chapters, 44 articles and 66 verses, important principles adopted in the compilation of Islamic law, among others, are explained in the Guidelines for the Implementation of Duties and Administration of Religious Courts including; bilateral/parental principles, the principle of direct heirs and substitute heirs. The principle of ijbari, the principle of individuals, the principle of equal justice, the principle of inheritance due to death, the principle of blood relations, the principle of mandatory wills, the principle of egalitarianism, and the principle of limited retroactivity. ${ }^{5}$

Ownership disputes over land and buildings in the case of inheritance, in principle, have a relatively reliable evidentiary tool. Following the Civil Code, including; 1) Written evidence, such as certificates issued by the National Land Agency (BPN), deeds of sale and purchase, grant deed, or other valid written evidence; 2) Witness, who knows for sure the ownership of the land and building that is the object of the dispute; 3) Evidence of allegation; 4) Confession and 5) Oath. Each of these five pieces of evidence has the strength of the evidence, and the most substantial evidence is the written evidence. So in the case of an inheritance lawsuit, there is a dispute over the rights of land and building of written evidence in this case freehold title is one of the most potent pieces of evidence.

The freehold title of land and buildings serves as a definite proof of the certificate holder, as long as there is no other evidence that is stronger than that. Strong evidence here means that the certificate of land and building rights is not absolute and only evidence. So the certificate of land rights and building according to the land registration system adopted by the Basic Agrarian Law (UUPA) can still be aborted or can be canceled as long as it can be proven before the Court that the land certificate is not valid. ${ }^{6}$

Gorontalo Religious Court is one of the first level Religious Courts in Gorontalo that deals with the cases of inheritance claims. Based on the annual Gorontalo Religious Court report for 2016, there were 11 inheritance cases and in 201729 cases. However, the focus of the study was one case of dispute over an inheritance that occurred in 2016 with Case Number. 0337/Pdt.G/2016/PA.Gtlo.

144.

${ }^{4}$ Mardani, Hukum Kewarisan Islam di Indonesia (1 ${ }^{\text {st }}$ Ed.; Jakarta: Rajawali Press, 2014), p. 143-

${ }^{5}$ Mahkamah Agung RI, Pedoman Pelaksanaan Tugas dan Administrasi Peradilan Agama Buku II (Direktorat Jenderal Badan Peradilan Agama, 2014).

${ }^{6}$ Bachtiar Effendie, Pendaftaran Tanah di Indonesia dan Peraturan-Peraturan Pelaksanaannya (Bandung: Alumni, 1993), p. 25. 
This case involves the heirs who are legitimate based on their descent as plaintiffs and the heirs who are adopted children of legitimate heirs.

This case is a matter of inheritance which, in its final verdict at the First Level Religious Court, states that the grant deed arises in the object of the dispute is invalid. The adopted child who controls the inheritance, in this case, is not a legitimate adopted child based on a court decision and declares that he is not legally binding. The verdict of the Gorontalo Religious Court sentenced the defendants to leave the object of the dispute for further execution.

The case was once disputed in the District Court with the same object but was different in its decision. case Decision in Gorontalo District Court with Case Number 38/Pdt.G/2012/PN.Gtlo. regarding property disputes acting as plaintiffs are adopted children while legal heirs are as defendants. The verdict of the Gorontalo District Court judges stated something different from the inheritance decision in the Gorontalo Religious Court. The Gorontalo District Court states that the grant deed arising on the object of the dispute has legal and binding legal force, states that adopted children, in this case, are valid based on the judge's judgment, and states that the freehold title in the case is legally binding.

Based on the two different verdicts but with the same object of dispute and related parties inside are the same person. So it is worth researching to find out how the application of the law and the consideration of judges in proving inheritance lawsuits in case verdict Number 0337/Pdt.G/2016/PA.Gtlo. which in its decision states that freehold title has no binding legal force.

\section{DISCUSSION}

\section{A. About Case Number 0337/Pdt.G/2016/PA.Gtlo.}

The verdict research shows that in this case there are many differences with inheritance cases that have been disputed in the Gorontalo Religious Court. It can be seen from the sitting disputed problems in this case that are so complicated to be solved in particular. The position of the heir who died 73 years ago when this lawsuit was registered at the Gorontalo Religious Court and the position of heirs have died. In the trial process, each Plaintiff and Defendant presented various kinds of evidence, such as; family tree, drawings of disputed objects, four certificates reversed from previous names in this case in the mastery of adopted children from the heirs (Defendant), death certificate and other documents.

The plaintiffs, in this case, are two people who are the heirs of the second descendants (grandchildren) of the remaining heirs. While for the defendants which numbered seven people, four people are adopted children of the heirs who have died, three people are the heirs of the third and fourth heirs. And the 
defendants are related institutions or officials who issued the grant deed and certificate, namely Notary and BPN (National Land Agency).

Although legally the verdict Number: 0337/Pdt.G/2016/PA.Gtlo. has binding legal force, but this was felt to be less convincing. If it is seen on the final decision between the statements of the plaintiff, defendant, witness, and the existence of evidence, basically, there is no synchronization. Especially regarding the position of inheritance, which is unclear because all the heirs are still alive, no one knows for sure whether this inheritance belongs to them or not. All of them only provide information based on what they have heard, let alone the heirs who died when the heirs who sued have not yet been born, and what they convey also cannot be proven in writing.

Meanwhile, the statement of the plaintiff's witness is almost the same position, both only know from the story of people, and even witnesses do not live contemporaneously with the testator. What is different is stated by the defendants in this case as adopted children of the heirs conveying that the inheritance is the joint property of the adoptive parents, not the inheritance of the testator as intended by the plaintiffs. However, if the inheritance is clear, it will be straightforward for the panel of judges to determine whether all documents arising from the inheritance are valid.

The issue concerns the position of adopted children who are declared invalid by the Gorontalo Religious Court. Examination of the case of heir meant in the case of dispute over ownership of the same object submitted at the Gorontalo District Court in 2012 in its decision that adopted children are recognized as legally adopted children. Then for the acquisition of grants, which are also considered invalid in the decision of the Gorontalo Religious Court, but in the decision of the Gorontalo District Court, it is considered valid. Likewise, the position of certificate deemed not legally binding in the Gorontalo Religious Court remains in the Gorontalo District Court considered valid.

\section{B. Application of Law in Proving Inheritance Lawsuit Case Number 0337/Pdt.G/2016/PA.Gtlo.}

The verdict that has been made in Case Number 0337/Pdt.G/2016/PA.Gtlo. shows that in applying the law, the panel of judges uses the method of argumentation (legal construction). The method of argumentation is also called the method of legal reasoning, redenering, or reasoning. This method is used if the law is incomplete, so to complete it, the argumentation method is used. This method aims to ensure that the results of judges' decisions in a particular event that they handle can fulfill a sense of justice 
and provide benefits for justice seekers. However, the value of a sense of justice and expediency is very relative. The fair value, in principle, requires the same legal events. In contrast, the value of the benefit lies in the use of the law both for justice seekers, law enforcers, legislators, administrators, and the wider community.

Kenneth J. Vandevelde mentions five steps of reasoning, namely: 1) Identifying possible legal sources, usually in the form of laws and court decisions; 2) Analyzing the source of the law to implement possible legal rules and policies in the regulation; 3) Synthesize the rule of law into a coherent structure, which is a structure that groups specific rules under general rules; 4) Examine the available facts; 5) Applying the structure of the rules to the facts to ensure the rights or obligations arising from the facts by using policies that are located in the rule of law in terms of solving severe cases.

As for the application of the law case No. 0337/Pdt.G/2016/PA.Gtlo, the judges use the method:

\section{Application of Argumentum Per Analogium Against the Position of Adopted Children}

An analogy is a method of legal discovery, where judges look for a more general essence of a legal event or legal action both as regulated by law or without regulation. The analogy method, as one type of legal construction, is usually often used in the field of civil law, and this will not cause problems.

The case mentioned above, in terms of the proper reconstruction, the method used by the panel of judges. The method of applying Argumentum Per Analogium (Analogy) about the process of adoption of children carried out by two heirs, namely Djaniba Liputo (adopted child; Maryam Liputo) and Simon Liputo (adopted child; Dolok Liputo, Reny Liputo, and Rely Liputo). In the facts of the trial, following what was stated by the defendants I, II, III, and IV, who were adopted children, all of them admitted that their status as adopted children was indeed actual and controlled some objects of the dispute. Although, in total, they do not recognize that the object they occupy is part of the inheritance, because to their knowledge, the object occupied is shared property with their adopted parents.

Regarding the status of defendants I, II, III, and IV who are adopted children, the panel of judges in their decision stated that they did not recognize their status as adopted children with the following considerations:

1) Defendant I, Defendant II, Defendant III as Simon Pomahu Lipoeto's adopted children and Defendant IV as adopted children of Djanibah Binti Hutu Lipoeto, there is no evidence in the trial of the child abuse carried out by Simon Pomahu Lipoeto. Still, it is revealed in the statement Defendant witnesses and Defendant witnesses that Defendant I, Defendant II, and Defendant III are maintained by the late. Simon Pomahu Lipoeto, this 
means that it cannot be said to have legal force on the status of Simon Pomahu Lipoeto's adopted children;

2) Considering that concerning the position of Defendant IV as an adopted child of Djanibah Binti Lipoeto, Defendant IV submitted evidence of letter T.IV. 4 stipulations regarding the adoption of children. However, the stipulation that became the applicant was Defendant IV Maryam Liputo because Djanibah had died;

3) Considering, that this stipulation is contrary to the provisions of adoption according to Islamic law, let alone Defendant IV who is the petitioner as the complainant in the determination of the court, the person who should be the petitioner is Djanibah Binti Hutu Lipoeto and not Defendant IV because an individual cannot request adopted as an adopted child, even though the faction of Defendant IV had lived together with the Djanibah Binti Lipoeto;

4) Considering, that in connection with the adoption of the child, it is necessary to pay attention to the formal requirements according to the instructions of the Holy Quran surah al-Ahzab verse 5.7

5) Considering, that based on the considerations as mentioned above, evidence T.IV.4 does not have the legal power to be used as evidence as adopted children, and if Defendant I, Defendant II, Defendant III, and Defendant IV continue to feel as adopted children then the right adoptive children's rights are according to the instructions of the Compilation of Islamic Law to obtain compulsory testaments of no more than $1 / 3$ of inheritance, the legal route of which is that the adopted child sues the heirs to fulfill the rights of the adopted child;

The panel of judges did not recognize the status of the defendants I, II, III, and IV as adopted children. It did not recognize the evidence of the decree concerning the adoption of the children of defendant IV. The panel of judges considered that there should be a ruling made by each adoptive parent in the Court for the adoption of a child. Although this has been explained by the defendants, who are adopted children that based on the Supreme Court Jurisprudence of the Republic of Indonesia dated May 15, 1990, No. 14413K/PDT/1988 which states that an adopted child is not solely dependent on the formalities of the child, but seen from the fact that there is that since he was a childhood cared for, circumcised and married by his adoptive parents. ${ }^{8}$ It can be concluded that the status of adopted children of the four adopted children can be recognized because, indeed, since childhood, they have been cared for and adopted as children by both adoptive parents.

The verdict of the Gorontalo District Court concerning case Decision No. 38/Pdt.G/2012/PN.Gtlo., regarding disputes over ownership rights, which were filed by the plaintiff, in this case, were adopted children adopted by children who

${ }^{7}$ Al-Mehri, A. B. (Ed.). The Qur'ān: With Sūrah Introductions and Appendices: Saheeh International Translation (Maktabah Booksellers and Publishers, 2010).

${ }^{8}$ Republic of Indonesia, Republic of Indonesia Supreme Court Jurisprudence May 15, 1990 Number. 14413K/PDT/1988. 
were prosecuted in the case of inheritance in the Gorontalo Religious Court case No. 0337/Pdt.G/2016/PA.Gtlo. In the decision of the Gorontalo District Court in its legal considerations, the panel of judges stated that until now in the community, it is still recognized and known as the adoption of children based on customs/habits can occur if the child is clear from a young age. , until he was an adult, cared for, educated, raised, and lived with his adoptive parents. Then it can be considered as an adopted child and can also be appointed based on a court decision. Based on these considerations and the facts of the trial the community that adopted children have lived together, cared for, raised, educated to get married, by their adoptive parents, Simon Liputo and Ema Liputo, the panel of judges believes that they are legitimate adopted children who are entitled to receive the inheritance of their adopted parents.

However, despite the existence of jurisprudence of the Supreme Court and the decision of the Gorontalo District Court can be accepted in common sense. But the panel of judges stated that the adopted child must be proven based on the court's verdict. In Islamic law, the adopted child can inherit $1 / 3$ of the inheritance based on Islamic Law Compilation in Article 209 paragraph (2), adoptive children who do not receive a will are given the mandatory wills as much as $1 / 3$ of the inheritance of their adopted parents. ${ }^{9}$

The verdict of this panel of judges has raised new problems. If it refers to the adoption of children in positive law in Indonesia, it is based on Law No. 23 of 2002 concerning Child Protection with implementing regulations in the form of Government Regulation (PP) No. 54 of 2007 concerning Implementation of Adoption of Children, and is explained in more detail in Minister of Social Affairs Regulation No. 110 of 2009 (PERMEN) Regarding the Requirements for Adoption of Children.

The application of the law using the Argumentum Per Analogium method in the case of adopted children above is intended to apply a special regulation in the constitution and then present general provisions that are not written in the constitution. Then also derived from the principles contained therein and concluded from the general provisions that specific events that are not regulated by the constitution but are similar. General rules not written in the constitution are applied to specific events not regulated in the constitution but are similar or similar to events set out in the constitution. Sometimes the laws and regulations are too narrow in scope; the judge can apply this method to the same or similar events.

${ }^{9}$ Republic of Indonesia, Presidential Instruction No. 11991 concerning the Compilation of Islamic Law in Indonesia. 
The opinion of the panel of judges in applying the law to the verdict does have a reasonably good rationale, especially about the mutual benefit between the heirs who have a stronger position and adopted children who are said to be legally illegitimate. However, the panel of judges needs to consider the constitution and other rules concerning adoption.

If it is seen at the rules, the process of the Child Protection Act in which there are requirements for the adoption of children, which is then followed by other regulations, was promulgated only in 2002. So before that year, there were no rules regarding the adoption of children that are valid in Indonesia legally and bindingly. The heirs in the case mentioned above, who carried out the adoption of children, were carried out before this rule came into effect, even before the existence of the Religious Courts Constitution. Similarly, the death of the heirs who make adoption of children who also died before the appointment rules of the child apply. So seeing this the burden to prove legally about the appointment of children to the defendants I, II, III, and IV should not be done by a panel of judges. They should still be considered in the decision as heirs who are obliged to obtain mandatory wills instead of ordering them to sue mandatory heirs to heirs. Besides, the judges should also consider the enactment of the constitution because the constitution is not retroactive.

\section{The Implementation Argumentum A Contrario on the position of Freehold Title}

The a contrario method is a way to explain the meaning of the constitution based on the different understanding of the actual events that are faced with the events set out in the constitution. If a particular event is regulated in the constitution, but other similar events are not, the opposite applies. This method allows the judge to find a law because if the constitution sets out certain things for the event and for events outside it the opposite applies. Therefore, the essence is to put forward the way of interpretation that is contrary to the understanding between the actual events that are faced with the events set out in the constitution.

In this argumentum a contrario method the emphasis is placed on the inequality of the event. Here the negative side of the constitution is needed. Then in the application of law Case Number 0337/Pdt.G/2016/PA.Gtlo. regarding the distribution of inheritance in the Gorontalo Religious Court. In this case, the panel of judges made a legal discovery in the context of interpreting the purpose of the constitution which was deemed unclear as to the explanation regarding the position of freehold title evidence.

The position of freehold title evidence, in the Civil Code the certificate is included in the authentic deed regulated in Article 1868 which reads; "An 
authentic deed is a deed made in the form specified by the constitution by or in front of the general authority authorized for that place where the deed was done." 10 This article clearly explains the authentic deed, so that deed made by an unauthorized official will be included under the deed category.

The power of proof of an authentic deed (AO) in the explanation of civil procedural law is perfect and binding evidence. Then the strength of formal evidence attached to the $\mathrm{AO}$ is explained in article 1871 of the Civil Code, that "all information contained in it is properly given and submitted by the signatory to the official who made it. Therefore, all information given by signatories in the $\mathrm{AO}$ is considered to be true as information is spoken and desired by the relevant parties". ${ }^{11}$

The explanation in Article 1868 and Article 1871 of the Civil Code mentioned above is a series of explanations from the strength of authentic deed evidence (AO). Based on the case decision Number: 0337/Pdt.G/2016/PA.Gtlo. Regarding inheritance dispute cases, in addition to determining heirs and establishing inheritance, there is also a part of the ruling stating that two authentic deeds (Freehold Title and Notary Deed) do not have binding legal force and penalize the parties to vacate and dismantle the object of a dispute as well as what which is explained in the following decision;

1) To punish Defendant I, Defendant II and Defendant III or anyone else to dismantle and vacate the inherited object which they control to be handed over to the plaintiff as the heirs of the testator;

2) To punish Defendant IV and Defendant $V$ or anyone to disassemble and vacate the inherited object under their control and then submit it to the plaintiff as the heirs of the testator;

3) To state that Freehold Title number 375 on behalf of Emma Lipoeto which has been separated into 2 (two) certificates is declared as not having binding legal force;

4) To state that Freehold Title number 966 in the name of Defendant I (Dolok M. Liputo) Defendant II (Renny Liputo/Reni Liputo) Defendant III (Relly Liputo) does not have binding legal force;

5) To state Freehold Title number 374 on behalf of Elly Dungga Liputo has no binding legal force;

6) To state that the testamentary deed made by Defendant I, Notary Lisa Purnamawati Nento, SH, has no binding legal force;

7) To order the clerks of the Gorontalo Religious Court to lift the special confiscation of the object occupied by Defendant VII with certificate number 965, despite appeal, cassation, and reconsideration;

8) To state that the legal and valuable seizure of security carried out by the clerks of the Gorontalo Religious Court on November 7, 2016, for the object occupied by Defendant I, Defendant II, Defendant III, certificate number 966 in the name of Defendant I (Dolok M. Liputo) Defendant II

\footnotetext{
${ }^{10}$ Republic of Indonesia, Civil Code.

${ }^{11}$ Republic of Indonesia, Civil Code.
} 
(Renny Liputo/Reni Liputo) Defendant III (Relly Liputo) and the object occupied by Defendant IV and Defendant V certificate number 374 on behalf of Elly Dungga;

Based on the decision referring to the provisions of Article 1868 and Article 1871 of the Civil Code, the so-called authentic deed is proof that the strength of the evidence is strong and binding, as long as there is no other written evidence that can abort the value of the power of evidence. ${ }^{12}$ Especially in its legal considerations that Defendant I, who is the notary maker of the permanent deed, participated in its establishment and acknowledged that the deed he made was the actual deed.

The application of the argumentatum a contrario on the proof of freehold title in the case was carried out by a panel of judges as a result of the events that occurred behind the release of the freehold title in the hands of the defendants and then also because it was a case of inheritance. So from this series of events that have been interpreted upside down by the judges in their verdicts.

Previously, the plaintiff and some of the defendants had filed a lawsuit in Gorontalo District Court in 2012 with case number 38/Pdt.G/2012/PN.Gtlo., but the defendants in the case constituted the heirs lost the lawsuit and the freehold title in the hands of adopted children who were plaintiffs in the case was finally considered legal by the Gorontalo District Court the existence of statements made by Simon Liputo (adoptive parents) during their respective lives dated August 30, 1983. A statement dated March 6, 1963, which is evidence of the plaintiff in the case, wherein the statement clearly states that the person entitled to all objects move or do not move $\mathrm{k}$ belonging to Simon Liputo and his wife named Emma Liputo will be surrendered and become the property of Relly Liputo, Renny Liputo and Dolok Liputo (each as an adopted child). So that the Gorontalo District Court panel of judges concluded that the disputed object was not an inheritance but joint property between Simon Liputo and Emma Liputo, because there was not a single piece of evidence in the trial that stated that this was inheritance.

A different matter was shown in the verdict of the Gorontalo Religious Court when this case was brought down as the inheritance case, the power of freehold title was weakened as a result of the actual events that occurred from the emergence of the certificate in question, among others made in a condition that the grant giver was near death, in this case, Emma Liputo. A grant between Simon Liputo to his wife Emma Liputo (adoptive parents) was considered invalid because there was no grant to his wife. The last, according to the judges of the Gorontalo Religious Court, the case proved to be an inheritance. However, in the decision of

\footnotetext{
${ }^{12}$ Republic of Indonesia, Civil Code.
} 
the Gorontalo District Court, it was not proven that the object of suffering was inherited property, and even in the proof at the Gorontalo Religious Court, there was not one evidence in the trial which stated that the object of the dispute was inheritance.

\section{Implementation of Sociological Interpretation of Grant Acquisition}

Implementation of sociological interpretation, that is, the judge interprets the constitution following the objectives of establishing the constitution. The goal is considered more than the sound of the words. Sociological interpretation occurs when the meaning of the constitution is applied based on social objectives, regarding the acquisition of grants in Case Number 0337/Pdt.G/2016/PA.Gtlo., concerning the distribution of inheritance in the Gorontalo Religious Court, shows that there is an interpretation of the constitution based on social objectives.

Some authentic deeds such as freehold title and notary testamentary deed have been stated that there is no binding legal force in the case mentioned above. If seen from the facts of the trial contained in the decision of the panel of judges, the consideration was the acquisition of the defendants' grants, especially those with adopted children. The judge considers that the deed made does not have the strength of proof. It is based on normative rules for granting grants in Articles 210 to 213 of the Compilation of Islamic Law (KHI).

Article 210 paragraph (2) states that: "Assets granted must be the right of the grant giver." ${ }^{13}$ This article has been proven in court that the gifted assets are not shared assets of the grant giver, where the grantor has the same position as the defendant, namely the grandson of the testator. Grants given by grant givers to their children in this case as adopted children are an inheritance that still must be distributed to other heirs. Therefore, the panel of judges was of the view that the giving of grants had not been fulfilled, namely as the property of the grant giver.

Article 211 stated that: "Grants from parents to their children can be counted as an inheritance." 14 This grant giver gives grants, not to their children but their adopted children. Article 212: "Grants cannot be withdrawn, except for parents' grants to their children." ${ }^{15}$ This article contradicts the decision of the panel of judges stating that all authentic deeds contained in this case are not legally binding, meaning that the certificate deed is not valid indirectly.

\footnotetext{
${ }^{13}$ Republic of Indonesia, Presidential Instruction No. 11991 concerning the Compilation of Islamic Law in Indonesia.

${ }^{14}$ Republic of Indonesia, Presidential Instruction No. 11991 concerning the Compilation of Islamic Law in Indonesia.

${ }^{15}$ Republic of Indonesia, Presidential Instruction No. 11991 concerning the Compilation of Islamic Law in Indonesia.
} 
Article 213 states that: "Grants that are given when the donor grants are sick are close to his death, he must obtain the consent of his heirs." ${ }^{16}$ This article has also been proven in court that the awarding of grants is indeed carried out when the condition of the grantor is ill close to his death and does not get approval from other heirs, so that the grant can be declared by a judicial panel of judges. Grant deeds obtained by defendants I, II, and III cannot be accepted legally. Because it is obtained in ways that are not true following the facts of the trial and the facts in the community because the deed was done when the heir was made sick, in fact, in the Compilation of Islamic Law Article 195 Paragraph (1) states that a will is made orally before two witnesses, or in writing before two witnesses or before a notary public. ${ }^{17}$ The article has made it clear that what Emma Liputo did to give a will to her adopted child before a notary is legal..

In line with the decision of the Gorontalo District Court No. 38/Pdt.G/2012/PN.Gtlo., that a testamentary grant is considered valid. The consideration was that Simon Liputo, who had died first, then Emma Liputo, only followed up on her husband's message, Simon Liputo, by making a testamentary grant, dated May 12, 2002, before a notary named Lisa Punawati Nento, SH. stating that the grant giver inherits its assets in the form of Freehold Title No. 375, covering an area of $1,950 \mathrm{M}^{2}$ on which there are residential houses occupied by his adopted child, located in the Tapa sub-district, Sipatana District, Gorontalo City, on behalf of Emma Liputo. However, the decision of the Gorontalo District Court was not used as a basis for consideration by the judges of the Gorontalo Religion Court, who found other facts.

Application of Sociological Interpretation, the panel of judges took the middle ground of this incident. Judge's consideration, in this case, is based on the evidence and facts of the trial without considering the decision which has permanent legal force from the Gorontalo District Court. Grant recipients unanimously acknowledge that the object of the given grant is a joint property of the grant giver, as a result of the grant giver having no children. Hence, as an adopted child, the grant recipient states that they are also entitled to obtain. But through sociological interpretation, there is a gap between the positive nature of the law with legal reality and social facts as well as the facts of the trial, and the judge interprets it by stating an authentic deed obtained incorrectly. It is declared no binding legal force.

\footnotetext{
${ }^{16}$ Republic of Indonesia, Presidential Instruction No. 11991 concerning the Compilation of Islamic Law in Indonesia.

${ }^{17}$ Republic of Indonesia, Presidential Instruction No. 11991 concerning the Compilation of Islamic Law in Indonesia.
} 


\section{Judge's Considerations in Approval of Lawsuit Case Number 0337/Pdt.G/2016/PA.Gtlo.}

The verdict made on Case Number. 0337/Pdt.G/2016/PA.Gtlo. concerning the case of inheritance in the Gorontalo Religious Court, which has permanent legal force. There are several legal considerations and arguments of the judge in deciding the case, including 1) the comparative method in determining the proof of an authentic deed; 2) considerations based on the historical existence of freehold title; and 3) sociological considerations of the position of heirs.

\section{Comparative Methods in Determining the Authenticity of a Deed}

Consideration based on the comparative method of determining this authentic deed becomes part of the judge's consideration in applying the applicable legal rules. The application of the judges' law considers the value of proof of certificate strength, which is an authentic deed whose fair value is valid and binding. As explained in the Civil Code by comparing the strength of a grant deed made by a notary public. Authentic deed in the explanation of the acquisition of a grant in the Compilation of Islamic Law (KHI), basically grants should not be canceled except for parent grants to their children. And the way to get a grant should be done in a condition where the donor is still healthy, not in the condition that the donor is near death. As was done by the defendants in the case above. It is supported by an incorrect explanation in the Qur'an surah An-Nisaa verse 176.

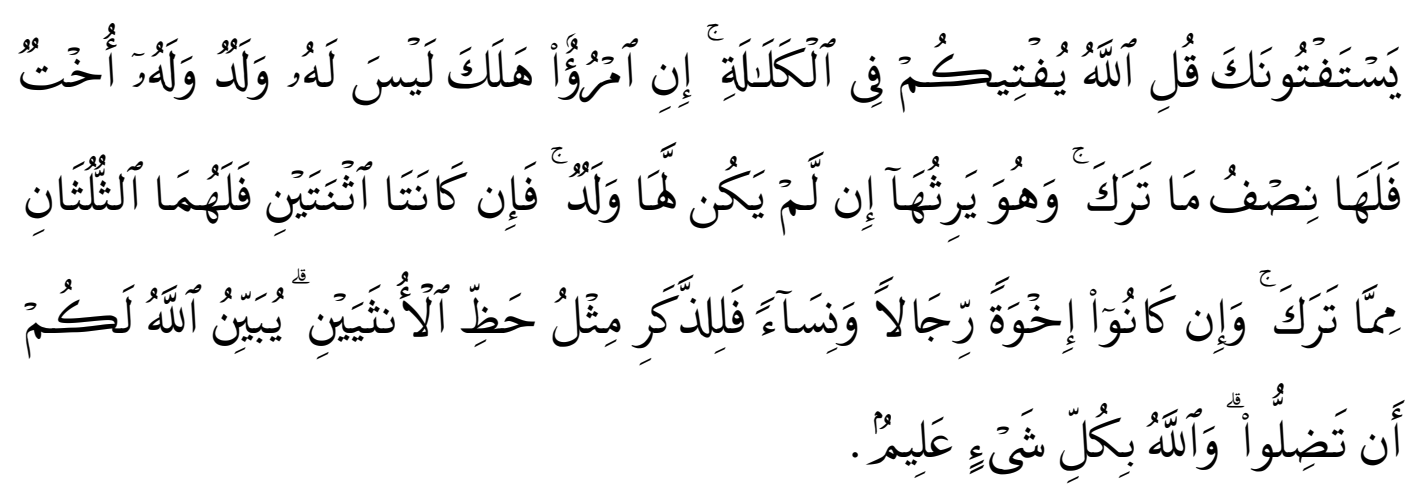

The translation:

They request from you a (legal) ruling. Say, "Allah gives you a ruling concerning one having neither descendants nor ascendants [as heirs]." If a man dies, leaving no child but [only] a sister, she will have half of what he left. And he inherits from her if she (dies and) has no child. But if there are two sisters [or more], they will have two-thirds of what he left. If there are both brothers and sisters, the male will have the share of two females. Allah makes clear to you (His law), lest you go astray. And Allah is Knowing of all things. ${ }^{18}$

${ }_{18}$ al-Mehri, A. B. (Ed.). The Qur'ān: With Sūrah Introductions and Appendices: Saheeh International Translation (Maktabah Booksellers and Publishers, 2010). 
Based on normative considerations in the Holy Quran Surah An-Nisa/4: 176, the Civil Code and KHI rules, the judges considered that the method of obtaining freehold title conducted by the defendants I, II, and III, could not be maintained and must be declared as having no binding legal force. The reason that strengthened the judge in deciding was the methods of the defendants I, II, III, and IV in obtaining the invalid certificate. How to force the heirs who are the adoptive parents of the defendants. It was based on the testimony of witnesses carried out by the defendants to obtain a freehold title.

Land certificate or freehold title, which is often used as evidence in litigation in a court, is categorized as an authentic deed whose evidence is strong and binding. Although during the trial process, the defendants I, II, and III never acknowledged that obtaining the land certificate was done by coercion. In their answer during the trial, they stated in essence that the object that the defendant controlled was no inheritance from the heir but a shared asset between the deceased. Simon Bin Pomahu Lipoeto, with his wife Emma Lipoeto, the foster parents of the defendant and the object, has been certified. The object occupied by Defendant VII has permanent legal force, namely the existence of certificates and decisions of the court of the first instance up to the level of cassation regarding ownership disputes.

The preceding has also been proven in the decision of the Gorontalo District Court in Case Number 38/Pdt.G/2012/PN.Gtlo. about property disputes. In its decision, no one can prove that the object of the dispute is inheritance, the argument of the plaintiff (adopted child) stating that the property is shared property with his adoptive parents. The same thing was conveyed by Notary, who is also a part of Defendant I who issued the deed of grant. In the answer that the grant deed issued was indeed following the procedure, but the panel of judges had a different opinion. Information from representatives of the panel of judges and substitute court clerks that certificates issued by notaries do not have binding legal force.

Defendant I, Defendant II, Defendant III, and Defendant IV and also participated in Defendant I, they did legal actions not based on the historical position of the testator. The Defendant made a deed related to the object, but they are not the heirs of the heirs so that the act of the heirs is not based on the legal force as the relationship in the heirs. Thus, what was done by the defendant, who was ratified through a notarial deed, did not have binding evidence. Based on Defendant I's confession that there was a Simon Bin Pomahu Lipoetu grant to his wife Emma Lipoeto, this contradicted the principles of inheritance in Islam, which is not permitted by a husband to grant a wife because his position is the heirs of her husband, and vice versa. 
Testimony of witnesses from Defendant I, Defendant II, and Defendant III, although 2 (two) witnesses were submitted, the witnesses only knew about the time that the object was controlled by Defendant I, Defendant II, and Defendant III. While the witnesses did not know the origin of the object, even the witnesses did not know if the object was a joint treasure between Simon Bin Pomahu Lipoeto and his wife Emma, as the Defendant, I argued in his rebuttal. Likewise, the statements of Defendant IV witnesses cannot be considered because only a witness, because the witness must have at least 2 (two) people (unus testis nullus testis) following Article 306 R.Bg.

The power of the plaintiff's evidentiary instrument was further strengthened by the evidence presented by Defendant VII, both letters and statements of 2 (two) Defendant VII's witnesses. The witness' testimony has corresponded to explain that the object is inherited from the heir of Hutu Lipoeto. The judges considered that the evidence presented by the defendant was unable to break the evidence presented by the plaintiff. Then the plaintiff has been able to prove the arguments of the lawsuit.

Furthermore, the panel of judges considered the status of the testamentary grant made by the defendant, that the deed made did not have the power of proof. So based on normative rules Article 210 to 213 of the Compilation of Islamic Law, states: "Assets granted must be the right of the grantee (Article 210)," Grants from parents to their children can be counted as an inheritance "(Article 211)," Grants irrevocable, except for the parents' gift to their children "(Article 212)," Grants that are given when the recipient is sick is close to his death, he must obtain the consent of his heirs "(Article 213).

Besides, in the principles of proof of law, one of the principles is the principle of acta publica probant sese ipsa, where this principle is related to the proof of an authentic deed. It means that a deed that appears to be authentic and fulfills specified conditions, the deed is valid or considered to be an authentic deed until proven otherwise. The burden of proof lies in who questions the authenticity of the deed.

Thus, those who can prove the validity of the authentic deed, in this case, the freehold title, which is the property of the defendants, is charged to the plaintiffs themselves. However, if seen from the facts contained in the decision of the judges of the Gorontalo Religious Court the authentic deed which was declared to be of no binding legal force was only based on historically obtaining the authentic deed not because there were other evidences that substantiated the arguments of the plaintiffs. 
Approval of the letter in Constitution No. 5 of 1960 concerning Basic Regulations on Agrarian Principles was never called a land certificate. Still, as found in Article 19 Paragraph (2) letter c, there was stated a "certificate of rights evidence". ${ }^{19}$ In standard terms, this proof of title has often been interpreted as a land certificate. So it can be said that the Land Certificate is a certificate that proves someone's right to a piece of land. In other words the situation states that there is someone who owns specific parcels of land and the possession has strong evidence in the form of a letter made by the competent authority; this is what is called a land certificate.

The release of the freehold title made by the National Land Agency (BPN) of Gorontalo City can be binding and robust evidence in determining the disputed land rights. Because, if the heirs should feel they have more rights to the disputed land in this case as heirs, then why in 2015 did the plaintiffs file a claim as heirs. Whereas this first certificate was made in 1991 and then reversed the names on behalf of the defendants I, II, and III in 2008. It should have been at this time that the plaintiffs who as heirs filed their claims to get their rights.

The acts of the plaintiffs who just filed a lawsuit on inheritance disputes in 2015 should be suspected of something hidden. Because the lawsuit arose when the heirs in this case, the adoptive parents of the defendants I, II, and III had died. It can raise question marks about what causes the new plaintiffs to sue this matter, even if if this lawsuit is carried out when the heirs (adoptive parents of defendants I, II, and III) are still alive, they may be able to meet the bright spot regarding the position of inheritance assets disputed.

Basically there is nothing wrong with the verdict of the panel of judges who granted part of the plaintiff's claim, all in accordance with the procedures and considerations of the panel of judges. However, normatively, the panel of judges should still consider the duration of the inheritance of the new estate being sued and the clarity of the status of the inheritance. Because, what is in the facts of the trial is not necessarily the same as what is in reality on the ground. Although what is claimed by the plaintiffs is clear and in accordance with the facts of the trial, they must consider other things that are possible to be considered.

The purpose of proving a civil case in it is to resolve disputes between litigants. The civil process is the process of resolving a dispute between two parties. In accordance with the legal objectives in essence, then with proof in the civil process, it aims to resolve disputes between parties who litigate, in the fairest way. By providing legal certainty for both the litigants and the community in general, by Principles.

${ }^{19}$ Republic of Indonesia, Constitution No. 51960 concerning Basic Rules of Agrarian 
not forgetting the usefulness of the judge's decision on the general public. Philosophically it can be said that the purpose of the proof is: "Quod Bonum Felix Faurtumque", what is good, happy and gifted (by Allah swt).

\section{Historical Considerations Based on the Existence of Freehold Title}

Judges' considerations are based on the historical existence of freehold title regarding inheritance disputes, the panel of judges' considerations are based on events that occur with the compatibility between the evidence and the facts of the trial. In this case put written evidence as the primary evidence. Written evidence submitted by the plaintiffs is none other than the grandchild of the testator with his fourth wife. It shows that the one who initially occupied the land in dispute was Maimuna Liputo. She is a descendant of heirs with his fourth wife, even though according to what is stated in the chronology of events in the plaintiff's claim, that those who occupy and build the first house in the inherited land are the children of the testator with his first wife, namely Lipahu Pomahu and Janiba Liputo.

Currently, the house is controlled by adopted grandchildren from Pomahu Liputo (adopted son of Simon Liputo), namely Dolok Liputo, Renny Liputo, and Relly Liputo. While Maimuna Liputo (son of the heir with his 4th wife) also built a house on the land. Based on the statement in the plaintiff's claim that Maimunah Liputo was only given a portion of the land by Djaniba Liputo (the heir's son to the first wife) who currently owns the house under the control of Febby Prasetyo (greatgrandchild of Maimunah/Defendant VII).

Therefore, it is clear that the first occupants of the land disputed by the plaintiffs and the defendants are descendants of the testator and his first wife. Then the land certificate that first came out was the land certificate belonging to the heir's grandson with his first wife, which came out on May 18, 1991. Now the names of the defendants who are adopted children of the heir's grandchildren with his first wife (Simon Liputo).

As for the Testamentary grant, the contents of which explained that there was a testamentary grant. As the giver of the grant was Emma Lipoeto, the recipient of the grant was her niece, namely Dolok M. Liputo, Renny Liputo and Relly Liputo made at Notary Lisa Purnama Nento, SH on May 12, 2003 which was also brought up in this case. Although based on information from witnesses and the plaintiffs, this grant was obtained in an improper way by the defendants.

However, it can be admitted that although the certificate is based on the statements of witnesses and the plaintiffs, historically it was obtained in ways that were not correct; in this case there was an element of coercion against the adoptive parents (heirs/grandchildren) to sign the notarial deed. But the defendants since their childhood are adopted children (Emma Liputo and Simon Liputo) who are 
cared for, raised and financed until they become successful. And vice versa even though their status is only as adopted children but they until the end of their foster parents' life still live together. The defendant took care of his adoptive parents who were sick and did not leave the house until now.

Written evidence is something that contains information about an event, situation, or certain things. In the civil procedural law, there are several types of written evidence including 1) a letter that is something that contains reading signs intended to pour out one's heart or to convey one's thoughts and is used as proof. 2) A deed is a letter as evidence that is signed, containing events that are the basis of a right or engagement, which was made deliberately for the purpose of proving.

Based on the previous explanation, it can be concluded that historically the panel of judges considered the facts. The object of the dispute is the inheritance of Hutu Liputu which until now has not been shared with all of its legal heirs. So that any authentic letters or deeds that arise in this case are declared to have no binding legal force except for matters that are recognized by both parties.

\section{Sociological Considerations Against the Position of the Heirs}

The panel of judges reviewed how the social relations and position of each party that litigated. On this basis, the panel of judges decided that the inheritance which was the dispute between the parties in the litigation, was the inheritance from the heir. However, there is no evidence which states that the object of the dispute is the property of the testator. Including the presence of witnesses who do not know the exact position of the inheritance. The witnesses only knew based on genetic information, because the witness was a person who did not live during the heir.

The consideration of judges in determining the object of the dispute is inheritance has a basis. According to the panel of judges, there is a strong basis in the fact of the trial that the plaintiffs in this case are legitimate heirs based on lineage. While the defendants who control the inheritance are not legitimate heirs based on lineage. Therefore, for the sake of mutual benefit and to maintain the integrity of the family in dispute, the panel of judges considered the sociological aspects of this case.

Based on the facts of the trial, the witness evidence, statements from the plaintiffs and written evidence submitted by the parties in this case no one knew and showed the existence of disputed inheritance. Is this treasure a joint asset between the heir and his first, second, third or fourth wife or is it purely the heir's property. The witnesses who gave their statements in court were merely witnesses who did not see the incident firsthand. They never heard directly and did not see 
directly about the position of the disputed inheritance as well as the plaintiffs and defendants.

The witnesses presented at this trial were witnesses who still had a close kinship with the heirs. However, what they have said is only based on what they know from the stories that exist within the heirs who are still alive. So it can be concluded that the testimonies of these witnesses cannot be accepted in the process of proving the status of inheritance. The testimonies of witnesses can only prove the process of the birth of freehold title, starting from the submission of certificate changes on behalf of the defendants. The existence of assets that are the object of the dispute cannot be proven as an inheritance. Because the heirs and witnesses are people who do not live together with the heir, so they do not know for sure about the position of the inheritance. However, due to consideration of the sociological aspects of the judge stated that the disputed property is inherited from the heir.

\section{CONCLUSION}

The application of evidentiary law in the case of inheritance Case Number 0337/Pdt.G/2016/PA.Gtlo, based on the results of the ruling study found three methods of applying the law used by the assembly, namely, Application of Argumentum Per Analogium on the Position of Adopted Children, Application of Argumentum A Contrario Position of Freehold Title, and Implementation of Sociological Interpretation of Grant Obtaining. Application of Sociological Interpretation occurs when the meaning of the constitution is applied based on social objectives. Judge's considerations in proving inheritance claim Case Number 0337/Pdt.G/2016/PA.Gtlo, based on showing that in determining the legal considerations, the panel of judges uses three things, namely, a comparative method in determining the proof of an authentic deed, a consideration based on the historical existence of a freehold title, and sociological considerations of the position of the heirs.

\section{REFERENCES}

Effendie, Bachtiar. Pendaftaran Tanah di Indonesia dan Peraturan-Peraturan Pelaksanaannya. Bandung: Alumni, 1993.

al-Mehri, A. B. (Ed.). The Qur'ān: With Sürah Introductions and Appendices: Saheeh International Translation. Maktabah Booksellers and Publishers, 2010.

Mardani. Hukum Kewarisan Islam di Indonesia. $1^{\text {st }}$ Ed.; Jakarta: Rajawali Press, 2014.

Mahkamah Agung RI. Pedoman Pelaksanaan Tugas dan Administrasi Peradilan Agama Buku II. Direktorat Jenderal Badan Peradilan Agama, 2014. 
Judge’s Verdict Number. 0337/Pdt.G/2016/PA.Gtlo.

Judge's Verdict Number 38/Pdt.G/2012/PN.Gtlo.

Rahman, Fatchur. Ilmu Waris. ${ }^{\text {st }}$ Ed.; Bandung: PT Al Ma'arif, 1981.

Republik Indonesia, Yurisprudensi Mahkamah Agung RI Tanggal 15 Mei 1990 No. 14413K/PDT/1988. (Republic of Indonesia, Republic of Indonesia Supreme Court Jurisprudence May 15, 1990 Number. 14413K/PDT/1988)

Republik Indonesia, Instruksi Presiden No. 1 Tahun 1991 tentang Kompilasi Hukum Islam di Indonesia. (Republic of Indonesia, Presidential Instruction No. 11991 concerning the Compilation of Islamic Law in Indonesia)

Republik Indonesia, Kitab Undang-Undang Hukum Perdata. (Republic of Indonesia, Civil Code)

Republik Indonesia, Undang-Undang No. 5 Tahun 1960 tentang Peraturan Dasar Pokok-Pokok Agraria. (Republic of Indonesia, Constitution No. 51960 concerning Basic Rules of Agrarian Principles)

Syarkoni, M. Konflik Harta Warisan. $1^{\text {st }}$ Ed.; Yogyakarta: Pustaka Pelajar, 2007. 